\title{
Native Whey Induces Similar Adaptation to Strength Training as Milk, despite Higher Levels of Leucine, in Elderly Individuals
}

\author{
Håvard Hamarsland ${ }^{1, *}\left(\mathbb{D}\right.$, Mathias K. Johansen ${ }^{1}$, Fridtjof Seeberg ${ }^{1}$, Marie Brochmann ${ }^{2}$, \\ Ina Garthe ${ }^{3}$, Haakon B. Benestad ${ }^{4}(\mathbb{D})$ and Truls Raastad ${ }^{1(D)}$ \\ 1 Department of Physical Performance, Norwegian School of Sport Sciences, P.O. Box 4014 Ullevål Stadion, \\ 0806 Oslo, Norway \\ 2 Department of Health, Nutrition and Management, Faculty of Health Sciences, Oslo and Akershus \\ University College of Applied Sciences, 0130 Oslo, Norway \\ 3 Norwegian Olympic Federation, 0863 Oslo, Norway \\ 4 Section of Anatomy, Institute of Basic Medical Sciences, University of Oslo, 0317 Oslo, Norway \\ * Correspondence: havard.hamarsland@gmail.com; Tel.: +47-93445916
}

Received: 24 June 2019; Accepted: 27 August 2019; Published: 4 September 2019

\begin{abstract}
Background: Large amounts of protein $(40 \mathrm{~g})$ or supplementing suboptimal servings of protein with leucine are able to overcome the anabolic resistance in elderly muscle. Our aim was to compare the effects of supplementation of native whey, high in leucine, with milk on gains in muscle mass and strength during a period of strength training, in elderly individuals. Methods: In this double-blinded, randomized, controlled study, a total of 30 healthy men and women received two daily servings of $20 \mathrm{~g}$ of either milk protein or native whey, during an 11-week strength training intervention. Muscle strength, lean mass, $\mathrm{m}$. vastus lateralis thickness, muscle fiber area, and resting and post-exercise phosphorylation of $\mathrm{p} 70 \mathrm{~S} 6 \mathrm{~K}, 4 \mathrm{E}-\mathrm{BP} 1$, and eEF-2 were assessed prior to and after the intervention period. Results: Muscle mass and strength increased, by all measures applied in both groups $(p<0.001)$, with no differences between groups $(p>0.25)$. p70S6K phosphorylation increased $(1000 \%, p<0.045) 2 \mathrm{~h}$ after exercise in the untrained and trained state, with no differences between supplements. Total and phosphorylated mTORC-1 decreased after training. Conclusion: Supplementation with milk or native whey during an 11-week strength training period increased muscle mass and strength similarly in healthy elderly individuals.
\end{abstract}

Keywords: protein supplementation; amino acids; protein quality; resistance exercise; gerontology; mTORC-1

\section{Introduction}

Aging is associated with a loss of muscle mass and strength and if allowed to advance, this condition may proceed to sarcopenia, early loss of independent living [1], and several comorbidities [2,3]. The most promising intervention to prevent or counteract sarcopenia to date is resistance exercise in combination with appropriate nutrition with a focus on protein consumption [4]. Among the emerging causal mechanisms of sarcopenia, anabolic resistance, meaning a dampened responsiveness in skeletal muscles to the stimuli of resistance exercise and protein intake has received much attention in later years [5]. With a growing aged population, the need to develop effective interventions including exercise and nutrition is increasing.

The effect of resistance training and protein on muscle mass is manifested through the summation of transient periods with positive net muscle protein balance leading to an accumulation of muscle mass over time [6,7]. Thus, by optimizing each period of positive net muscle protein balance, greater positive 
changes in muscle mass can be achieved over time. The anabolic effect of a protein is dependent on the digestion rate and amino acid kinetics [8-10] and amino acid composition [11,12], in particular levels of leucine [13]. Acute studies have shown promising results for high leucine or leucine-enriched proteins in terms of stimulating muscle protein synthesis [13-15].

Our lab has previously shown that native whey, which is high in leucine, increases signaling related to translation, and muscle protein synthesis (MPS) to a greater extent than milk in elderly participants after resistance exercise [16]. Effects of protein supplementation in long-term training studies are less clear (Morton 2017) [17-20]. Native whey is manufactured by the filtration of unprocessed raw milk, leaving proteins complete. Producing whey by this method removes glycomacropeptides, which are low in leucine, thus increasing the leucine concentration of native whey by about $15 \%$ compared to regular whey and $25 \%$ compared to milk [21].

The aim of the current study was to examine whether previously reported short-term differences in anabolic signaling and muscle protein synthesis between native whey and milk [16] translates into differences in long-term adaptations of muscle mass and strength during a 11-week strength training regime in elderly participants. We also included an acute study at the beginning and at the end of the training intervention in order to investigate potential changes in anabolic signaling between the untrained and trained state.

\section{Materials and Methods}

\subsection{Participants and Ethical Approval}

Thirty-eight elderly (+70 years) men and women were included in the study (Table 1 ). The main outcome in this study was lean mass. As no previous study had compared different protein supplements in elderly individuals at the time, we based our power calculations on a combination of protein supplementation studies in the elderly $[18,19,22]$ and studies comparing different sources of protein supplementation in the young [23,24]. Our goal was to include 20 participants in each group to have an $80 \%$ power to detect a true difference of $1.3 \%$ with a standard deviation of $1.5 \%$. Unfortunately, eight participants withdrew from the intervention after inclusion. One withdrew after the first acute study, after which the participant experienced dizziness. Two withdrew due to arthritic pain. Three withdrawals were due to busy time schedules. Two participants experienced health issues, not related to the study, and were excluded due to low workout attendance. Prior to participation in the study, all participants completed a medical screening. Individuals with lactose intolerance, milk allergy, allergy to local anesthesia, habit of smoking, cardiovascular disease, or any injuries to the musculoskeletal system that would impede the ability to perform strength training were excluded from this study. One participant was on anticoagulants and 6 participants took statins. The use of any dietary supplements was prohibited during the intervention. If participants were using supplements, usage was halted at least two weeks prior to pre-testing. Participants were untrained and had no prior experience with heavy resistance exercise. The study was performed in accordance with the Declaration of Helsinki and approved by the Regional Ethics Committee for Medical and Health Research of South-East Norway. A written informed consent form was signed by all participants before entering the study. The trial was registered at clinicaltrials.gov as NCT03033953. Figure 1 shows a flowchart of the study. 
Table 1. Amino acid and macronutrient content of the supplements.

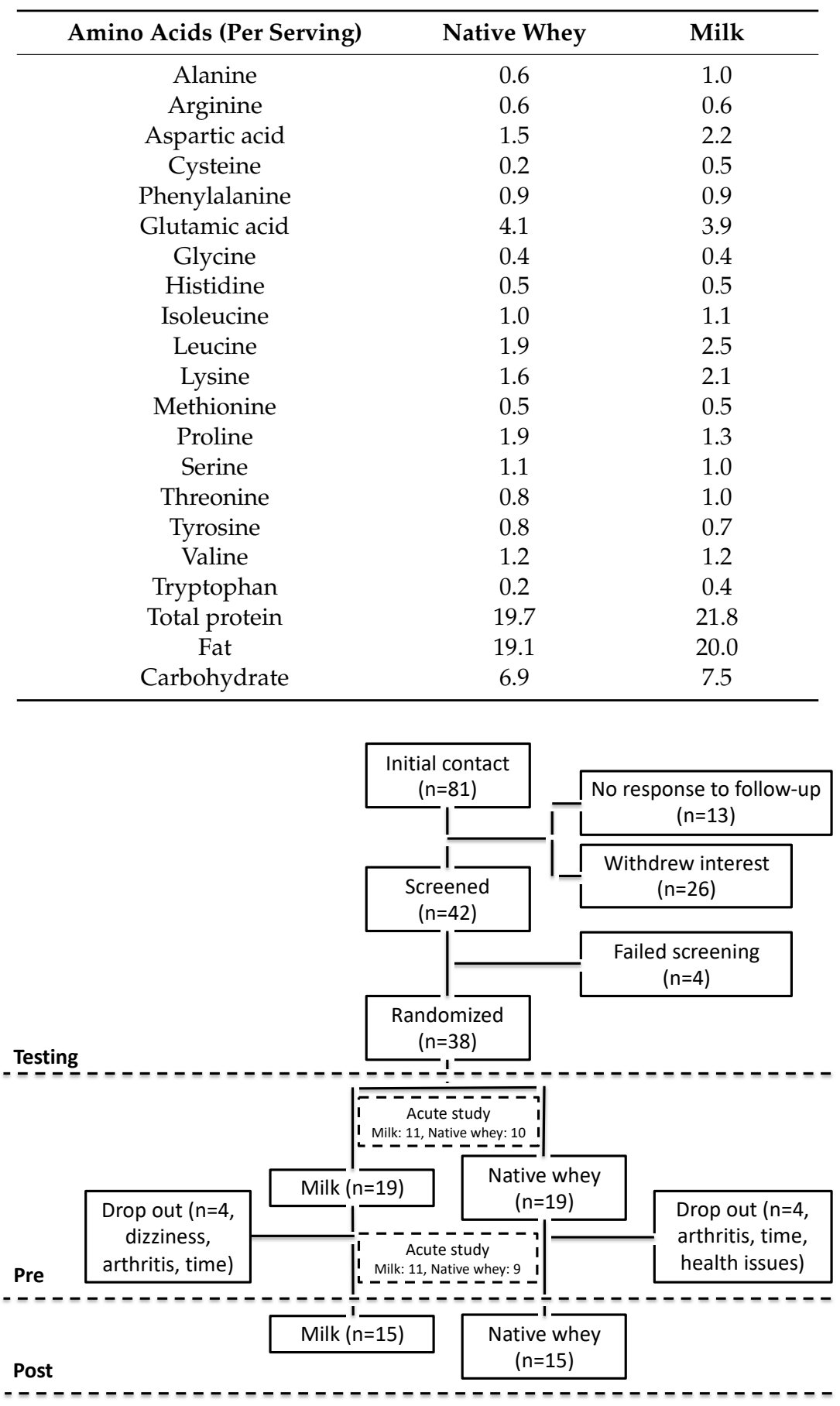

Figure 1. Flow chart diagram of study recruitment, enrollment, randomization follow-up, and analysis.

\subsection{Study Design}

This study was conducted as a double-blinded, randomized, controlled trial. Randomization was conducted using an online tool (www.randomizer.org/). Participants, trainers, and researchers involved in lab analysis were blinded to group allocation until analyzes were finished. The design involved 11 weeks of strength training totaling 33 workouts. A subgroup of participants $(n=20)$ took part in an acute study during the first and last workout sessions of the training period. As a result, muscle biopsies were collected in the untrained rested, untrained acutely exercised, trained rested, and 
trained acutely exercised state. Participants were randomized to one of two groups, receiving either native whey or $1 \%$ fat milk.

\subsection{Supplements}

Native whey was purchased from Lactalis ${ }^{\circledR}$ (Laval, Mayenne, France) and the $1 \%$ milk was manufactured by Tine ASA (Oslo, Norway). Supplements were matched on macronutrients by adding cream (Tine ASA, Oslo, Norway) and lactose (Arla foods, Viby, Denmark) to the native whey protein. Supplements were spray dried into powder form, to be mixed with $0.4 \mathrm{~L}$ of water before intake. The supplements had a similar flavor and appearance. The amino acid and macronutrient content of the supplements are listed in Table 2 . On training days, one serving was consumed immediately after training, and one serving was consumed in the afternoon. On days with no training, supplements were consumed in the morning and in the afternoon. Supplements were consumed every day from the first training session to the last day of testing. The decision to distribute the protein as described was made in order to optimize the anabolic effects of the supplementation over the whole day, in contrast to our previous study, aiming to maximize the anabolic effects for five hours after exercise. Adherence to the supplementation schedule was reported by the participants each training and recorded on each training day by the trainers.

Table 2. Participants characteristics.

\begin{tabular}{cccc}
\hline & Milk & Native Whey & $p$ Values for Group Differences \\
\hline $\mathrm{N}\left(\mathrm{o}^{\top} /\right.$ o $)$ & $15(9 / 6)$ & $15(9 / 6)$ & \\
Age (years) & $74.3 \pm 3.6$ & $72.9 \pm 1.8$ & 0.18 \\
Body mass $(\mathrm{kg})$ & $74.6 \pm 14.0$ & $78.3 \pm 16.2$ & 0.81 \\
Fat mass $(\mathrm{kg})$ & $22.1 \pm 7.0$ & $23.9 \pm 8.9$ & 0.55 \\
Lean body mass $(\mathrm{kg})$ & $49.8 \pm 9.2$ & $49.5 \pm 10.9$ & 0.95 \\
Body fat $(\%)$ & $30.5 \pm 5.5$ & $32.0 \pm 9.1$ & 0.60 \\
VL thickness $(\mathrm{cm})$ & $2.1 \pm 0.4$ & $2.3 \pm 0.5$ & 0.20 \\
Leg press 1 RM $(\mathrm{kg})$ & $176 \pm 55$ & $158 \pm 50$ & 0.36 \\
Bench press 1 RM $(\mathrm{kg})$ & $46.8 \pm 20$ & $42.8 \pm 17$ & 0.56 \\
\hline
\end{tabular}

\subsection{Daily Food Intake}

Participants were asked to continue their normal dietary routine during the study. A trained dietitian conducted two 24 -h dietary recall interviews with each participant at week 1,5 , and 11 during the training intervention. The dietary nutrient content was analyzed using the software Mat på Data 5.1 (Mattilsynet, Oslo, Norway, 2009). Nine participants had a protein intake below $1.0 \mathrm{~g} \times \mathrm{kg}$ body weight ${ }^{-1}$ at the first recording and were recommended to increase their protein intake and given the necessary guidance to achieve this. These participants all increased their protein intake, but four participants (two in each group) were still below $1.0 \mathrm{~g} \times \mathrm{kg}$ body weight $^{-1}\left(>0.89 \mathrm{~g} \times \mathrm{kg}\right.$ body weight $^{-1}$ ) during the study.

\subsection{Training Program}

The training intervention consisted of a conventional whole-body resistance-training program consisting of three workouts each week. Loads ranged from 12 to $6 \mathrm{RM}$, for 1 to 3 sets and progressed from higher to lower repetition ranges during the 11 weeks of training. During the program, Mondays started at 1 to 2 sets of $12 \mathrm{RM}$ for the first three weeks before adding another set to several exercises in weeks 4 to 9 and again in weeks 10 to 12. Fridays progressed from 1 to 2 sets of 8 RM in weeks 1 to 6 to 2 to 3 sets of 6 RM in weeks 7 to 12 . On Mondays and Fridays, workouts were conducted with maximal training load and intensity for the given repetitions. On Wednesdays, workouts were submaximal, using $90 \%$ of the load on the previous Monday for the same amount of reps. In addition to the exercises listed under the standardized workout, participants also did weighted back-extensions and abdominal 
exercises at the end of each workout. Inter-set rest periods lasted for 2 to $3 \mathrm{~min}$. Qualified trainers oversaw participants during all training sessions, and continuous rotation of instructors between participant groups throughout the period minimized any potential differences in coaching.

\subsection{Dual-Energy X-ray Absorptiometry}

Body composition was assessed in the overnight fasted state by dual energy X-ray absorptiometry (Lunar iDXA GE Healtcare, Madison, Wisconsin, USA using the enCORE Software Version 14.10.022) prior to and after the intervention. No training or testing was allowed for $48 \mathrm{~h}$ before the scan. Whole body scans were completed in the supine position, providing values for lean tissue, fat mass, and bone mineral content. The analysis of lean mass has a coefficient of variation $<1 \%$ in our lab.

\subsection{Ultrasonography}

M. vastus lateralis thickness was assessed by ultrasound at $40 \%$ of the femur length measured from distal to proximal. At the first assessment, lines were drawn to indicate the point of measurement. After the scan, a transparent overlay was placed on the thigh. The assessments lines as well as characteristics, such as moles and scars, were copied by a permanent marker. For the post-assessments, the assessment lines were marked on the skin through punctured holes in the overlay. Previous pictures of the individual participant were displayed on a separate screen in order to relocate the probe based on characteristics in the picture, such as connective tissue and blood vessels. The average of 3 images was used for each time point. Images were analyzed with OsiriX v 5.5.1 (Pixmeo, Geneva, Switzerland).

\subsection{Maximal Strength}

One repetition maximum (1 RM) in the leg press and chest press was tested prior to and after the intervention. Familiarization to the tests was performed one week before testing. After $10 \mathrm{~min}$ of brisk walking on a treadmill, a range of warm-up sets were completed before both exercises with 10, 6, 3, and 1 repetitions at $50 \%, 70 \%, 80 \%$, and $90 \%$ of the expected $1 \mathrm{RM}$, respectively. $1 \mathrm{RM}$ was achieved within 2 to 5 attempts, with 2 to 3 min of rest separating attempts. Knee flexion during leg press was set to $90^{\circ}$ and grip width in the chest press was standardized. Load increments during tests could be made by a minimum of $5 \mathrm{~kg}$ and $1 \mathrm{~kg}$ for leg press and chest press, respectively.

Isometric unilateral voluntary maximal contractions were assessed in the seated position in a custom-made knee-extension apparatus (Gym2000, Geithus, Norway), with a $90^{\circ}$ angle in the hip and knee joints. Chest and hip movement were restricted by a four-point harness. After three warm up sets at $25 \%, 50 \%$, and $75 \%$ of the perceived maximal effort, three attempts of $5 \mathrm{~s}$ were performed with one minute of rest between each attempt. Force was measured with a force transducer (HMB U2AC2, Darmstadt, Germany). The best contraction was used as a result of the test. The warm-up before the MVC test consisted of $5 \mathrm{~min}$ on a cycle ergometer, except when tested immediately after the workout sessions for the subgroup taking part in the acute study.

\subsection{Functional Tests}

In order to measure performance changes in daily activities, we included a timed stair climb and a timed chair rise. Familiarization to the tests were performed one week before testing. The stair climb was performed in a 2-level staircase (20 steps of length: $30 \mathrm{~cm}$ and height: $18 \mathrm{~cm}$ ). Participants were instructed to walk the stairs as fast as possible without transitioning into running. No arm-swing was allowed. The stair climb was performed with three different levels of load: Body weight, wearing a $10-\mathrm{kg}$ weight vest, and wearing a 10-kg weight vest while carrying two 5-kg weight discs. Participants had two attempts with each load. Performance was measured using photocells (Speedtrap 2, Brower Timing Systems, Draper, UT, USA).

For the timed chair rise, participants were instructed to stand with their arms crossed in front of a chair (height: $47 \mathrm{~cm}$ ), then to sit and stand five times as fast as possible. When sitting, both feet had to be lifted a few centimeters off the ground to demonstrate full transfer of weight to the chair, and when 
standing hips needed to be fully extended for the trial to be registered. Performance was measured using a pressure plate (Speedtrap 2, Brower Timing Systems, Draper, USA) placed on the chair and proper technique was ensured by test leaders.

\subsection{Blood Analyses}

The analysis of serum glucose, insulin, urea, and creatine kinase was done at Fürst Medical Laboratory (Oslo, Norway). Blood concentrations of amino acids were analyzed as previously described [21] with a EZfaast amino acid analysis kit (Phenomenex ${ }^{\circledR}$, Torrance, CA, USA) and gas chromatography/mass spectrometry (Shimadzu QP-2010 Ultra GCMS, Shimadzu Scientific Instruments, Columbia, MD, USA).

\subsection{Biopsy Collection and Pre-Analytical Processing}

Muscle specimens were sampled from the mid portion of $\mathrm{m}$. vastus lateralis by a modified Bergström technique with suction. The biopsies were grinded into a homogenate of soluble proteins (for western blot) and mounted for immunohistochemistry. Pre-analytical processing, such as freezing and homogenization, of muscle biopsies was completed as previously outlined [25].

\subsection{Western Blot}

Homogenates for western blot were handled as previously described [25], quantified with ChemiDoc MP (BioRad Laboratories, Hercules, CA, USA), and analyzed with Image Lab (v5.1, BioRad Laboratories, Hercules, CA, USA). Samples were run in duplicates, and all comparisons were made within each blot. Primary and secondary antibodies are listed in Supplementary Table S1.

\subsection{Immunohistochemistry}

Eight-micrometer-thick cross sections were blocked for $30 \mathrm{~min}$ with 1\% BSA (bovine serum albumin; A4503, Sigma Life Science, St Louis, MO, USA) in a 0.05\% Phosphate Buffered Saline with Tween $囚 20$ (PBS-T) solution (Cat\#524650, Calbiochem, EMD Biosciences) before being incubated with antibodies against myosin heavy chain II (SC71, hybriodomabank) and dystrophin (AbCam) in a blocking solution for $2 \mathrm{~h}$ at room temperature. This was followed by incubation with appropriate secondary antibodies (A11005 or A11001; Life technologies, Invitrogen) for $30 \mathrm{~min}$ at room temperature, before being covered with a coverslip and mounted with ProLong Gold Antifade Reagent with DAPI (P36935, Invitrogen Molecular Probes, Eugene, OR, USA). Muscle sections were then and left to dry overnight at room temperature. Between stages, the sections were washed $3 \times 5 \mathrm{~min}$ in a $0.05 \%$ PBS-T solution. Individual muscle fiber CSAs were analyzed, and measurements were calculated using TEMA software (Checkvision, Hadsund, Denmark). In total, 50 type I fibers and 50 type II fibers were analyzed on each section.

\subsection{Acute Strength Training Experiment}

In addition to the training study, 20 participants (milk: 9 and native whey: 11) performed an acute study as their first and last workout of the training intervention. Both sessions were performed after 3 to 4 days with no strenuous physical activity. In the overnight fasted state, participants ingested a standardized breakfast (50 energy percent ( $\mathrm{E} \%$ ) from carbohydrate, $8 \%$ from protein, and $42 \%$ from fat) consisting of oats $\left(0.85 \mathrm{~g} \times \mathrm{kg}_{\text {body mass }}{ }^{-1}\right)$, water, rapeseed oil $\left(0.2 \mathrm{~g} \times \mathrm{kg}_{\text {body mass }}{ }^{-1}\right)$, and 5 grams of sugar ( $30 \mathrm{~kJ}, 0.14 \mathrm{~g}$ protein, $0.36 \mathrm{~g}$ fat, and $0.84 \mathrm{~g}$ carbohydrates $\times \mathrm{kg}^{-1}$ body mass). Each participant received an individual meal plan for the length of the acute study. The plan was based on body mass and provided participants with $30 \mathrm{kcal} \times \mathrm{kg}_{\text {body mass }}{ }^{-1}$ and $1.3 \mathrm{~g}$ of protein per kg-1 $\times$ day $^{-1}$.

The workout was standardized and based on RM-load. Thus, the training load was increased from the first to the last acute bout in order to reach RM. The warm-up consisted of $10 \mathrm{~min}$ on a treadmill and specific warm-up sets with a submaximal weight for hammer squat, bench press, and seated 
rowing. The workout consisted of three sets of 10 repetitions, with a new set starting every $3 \mathrm{~min}$, and included hammer squat, leg press, knee extension, chest press, seated row, one set of close-grip pull down, and two sets of shoulder press. Figure 2 outlines the timeline of the study. Supplements were ingested within $5 \mathrm{~min}$ after the workout.

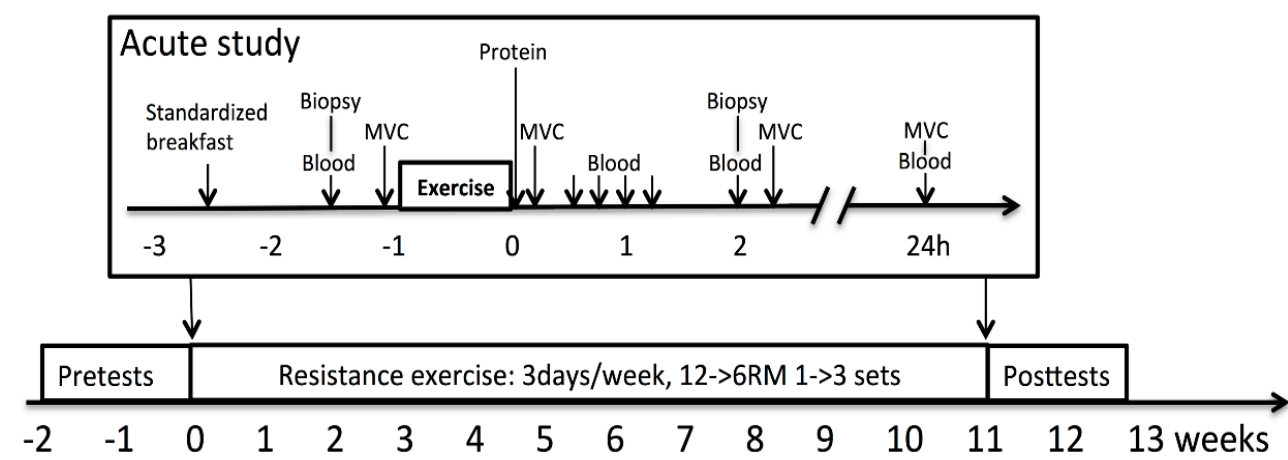

Figure 2. Timeline of the study.

\subsection{Statistics}

Non-normally distributed data (D'Agostino and Pearson omnibus normality test) were log-transformed before statistical analysis. All figures show data in the original form. A two-way ANOVA with repeated measures (time $\times$ group) was applied to test group differences pre- and post-11-week training intervention and relative changes from pre to post, and between the acute experiments. Sidak and Tukey's test was used as post-hoc tests to specify significant differences between selected groups and time points and all comparisons, respectively. As comparisons within groups for blood amino acid concentrations, glucose, insulin, urea, and creatine kinase (CK) were only made against before values and Dunnet's test was used as a post-hoc test.

Relative changes (\%) between groups from the pre- to post-training period were compared with an unpaired Student's $t$ test. Relative changes within each group were assessed with a paired Student's $t$ test. Statistical analyses were made using Prism Software (Graphpad 6, San Diego, CA, USA). All results are expressed as means \pm standard deviation (SD). Statistical significance level was set at $p \leq 0.05$.

\section{Results}

\subsection{Participant Characteristics and Compliance}

We observed no group differences in the baseline characteristics (Table 2). Participants' attendance was $33.0 \pm 0.9$ in the native whey group and $32.5 \pm 1.2$ in the milk group. Total training load (repetitions $\times$ sets $\times \mathrm{kg} \times$ sessions) during the training period was $249,000 \pm 65,000 \mathrm{~kg}$ for the native whey group and $252,000 \pm 60,000 \mathrm{~kg}$ for the milk group $(p=0.74)$. Compliance to the supplementation regimen was $99 \pm 1 \%$ for the native whey group and $99 \pm 1 \%$ for the milk group $(p>0.99)$. Daily energy intake and protein intake (g.kg body mass ${ }^{-1}$. day ${ }^{-1}$ ) increased by $27 \%$ in the milk group and $39 \%$ in the native whey group. The energy percent $(\mathrm{E} \%)$ from fat decreased in the milk group $(p=0.004)$ but not in the native whey group ( $p=0.177)$. The $\mathrm{E} \%$ from carbohydrates increased in both groups ( $p<0.01$ for both groups). No differences were observed between groups for total energy intake or macronutrients (Table 3).

\subsection{Muscle Mass and Muscle Fiber Cross-Sectional Area}

Significant muscle hypertrophy was evident for lean mass (milk: $6.3 \pm 3.6 \%$; native whey: $4.6 \pm 3.4 \%, p<0.001$ for both groups), thickness of the $\mathrm{m}$. vastus lateralis (milk: $7.2 \pm 5.3 \%$; native whey: $7.1 \pm 5.2 \%, p<0.001$ for both groups), and type II muscle fiber cross-sectional area (milk: $34.2 \pm 56.7 \%, p=0.021$; native whey: $33.8 \pm 27.4 \%, p<0.001$ ) in both groups. No change was observed 
for type I muscle fibers (milk: $4.7 \pm 22.0, p=0.62$; native whey: $2.8 \pm 19.7, p=0.89$ ). There were no between-group differences for any measures of muscle growth (Table 4 and Figure 3).

Table 3. Daily intakes of energy and macronutrients before and during the training intervention. Values are averaged from two $24-\mathrm{h}$ recall interviews. ${ }^{*}$ signifies change from pre. Significance level at $p \leq 0.05$.

\begin{tabular}{ccccc}
\hline & \multicolumn{2}{c}{ Milk } & \multicolumn{2}{c}{ Native Whey } \\
\hline & Baseline & Intervention & Baseline & Intervention \\
\hline Energy (KJ) & $7800 \pm 2100$ & $9400 \pm 1500 *$ & $7400 \pm 1900$ & $9800 \pm 1500^{*}$ \\
Protein g.kg body mass ${ }^{-1}$ & $1.0 \pm 0.3$ & $1.3 \pm 0.2^{*}$ & $1.1 \pm 0.3$ & $1.3 \pm 0.4^{*}$ \\
Protein (E\%) & $17 \pm 4$ & $17 \pm 3$ & $19 \pm 3$ & $17 \pm 2$ \\
Carbohydrate (E\%) & $39 \pm 5$ & $46 \pm 3 *$ & $39 \pm 6$ & $43 \pm 5^{*}$ \\
Fat (E\%) & $44 \pm 8$ & $37 \pm 4^{*}$ & $42 \pm 7$ & $40 \pm 6$ \\
\hline
\end{tabular}
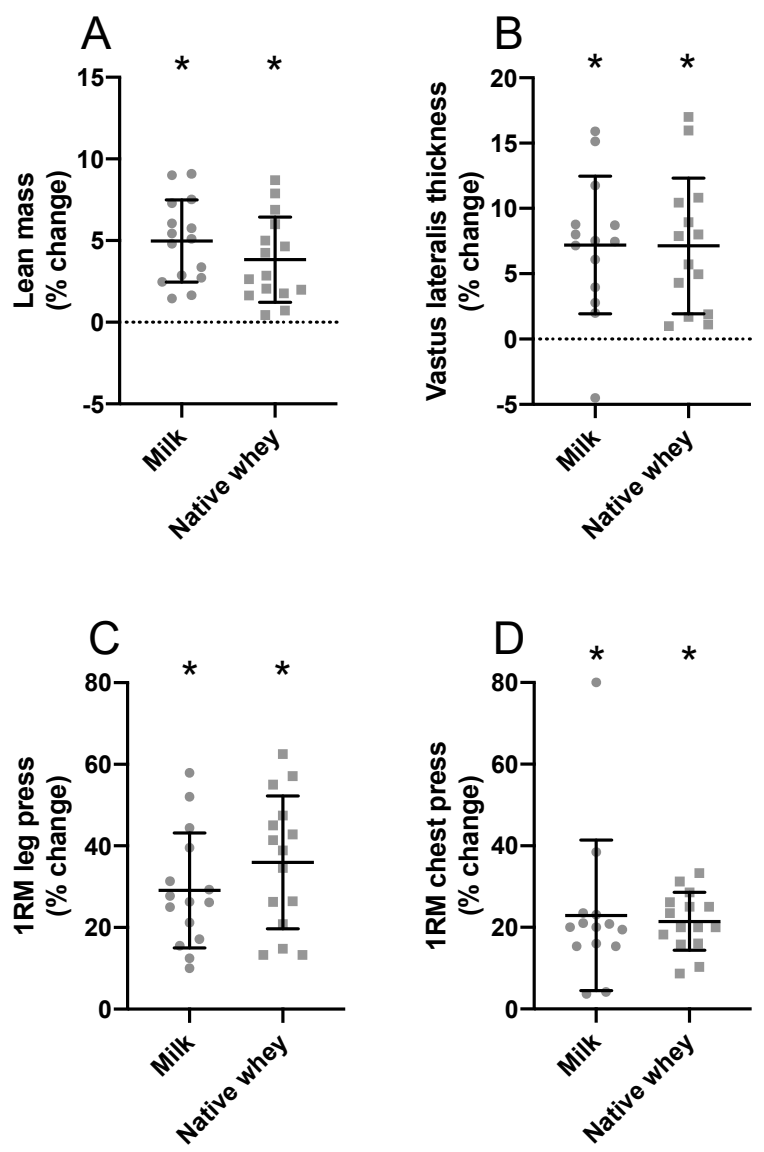

Figure 3. Relative changes in lean mass (A), m. vastus lateralis thickness (B), 1 RM leg press (C), and $1 \mathrm{RM}$ bench press (D) after a 12-week strength training and protein supplementation period in the elderly. Values are mean \pm SD. $n=15$ and 15 in the milk group and native whey group, respectively. * different from baseline, $p<0.05$.

\subsection{Muscle Strength and Performance}

After 11 weeks of strength training, all participants increased 1 RM in leg press (milk: $29.1 \pm 14.1$; native whey: $36.0 \pm 16.3 \%, p<0.001$ for both groups) and chest press (milk: $22.9 \pm 18.4 \%$; native whey: $21.5 \pm 7.1 \%, p<0.001$ for both groups). We observed no differences between groups for gains in strength (Table 4). The time to completion for the stair-climb trials improved by between $3 \%$ and $4 \%$ in the milk group and $6 \%$ and $8 \%$ in the native whey group and chair rise improved by $8.1 \pm 13.9 \%$ and $11.0 \pm 9.2 \%$ in the milk and native whey group, respectively. We observed no differences for changes in performance between groups (Table 4). 
Table 4. Changes in regional muscle mass, $\mathrm{m}$. vastus lateralis thickness, muscle fiber area, and myonuclei in elderly men and women receiving milk or native whey supplementation for 11 weeks combined with strength training.

\begin{tabular}{|c|c|c|c|c|c|c|c|}
\hline & \multicolumn{3}{|c|}{ Milk } & \multicolumn{3}{|c|}{ Native Whey } & \multirow{2}{*}{$p$ Values for Group Difference (\% Change) } \\
\hline & Pre & Post & $\%$ Change & Pre & Post & $\%$ Change & \\
\hline Body mass $(\mathrm{kg})$ & $74.6 \pm 14.0$ & $77.2 \pm 14.0$ & $3.6 \pm 2.2 *$ & $75.9 \pm 16.1$ & $78.3 \pm 16.2$ & $3.3 \pm 1.6^{*}$ & 0.618 \\
\hline Fat mass $(\mathrm{kg})$ & $22.1 \pm 7.0$ & $22.4 \pm 6.8$ & $1.7 \pm 5.3$ & $23.9 \pm 8.9$ & $24.4 \pm 8.9$ & $2.4 \pm 4.9$ & 0.721 \\
\hline Arm lean mass $(\mathrm{kg})$ & $5.6 \pm 1.5$ & $6.0 \pm 1.6$ & $6.4 \pm 3.6^{*}$ & $5.3 \pm 1.5$ & $5.6 \pm 1.5$ & $5.2 \pm 3.9 *$ & 0.377 \\
\hline Trunk lean mass $(\mathrm{kg})$ & $24.0 \pm 3.9$ & $24.8 \pm 3.7^{*}$ & $3.4 \pm 3.6^{*}$ & $23.7 \pm 4.8$ & $24.4 \pm 5.0 *$ & $3.0 \pm 3.1 *$ & 0.791 \\
\hline VL thickness $(\mathrm{cm})$ & $2.06 \pm 0.36$ & $2.21 \pm 0.39 *$ & $7.2 \pm 5.3^{*}$ & $2.28 \pm 0.51$ & $2.43 \pm 0.50$ * & $7.1 \pm 5.2 *$ & 0.971 \\
\hline \multicolumn{8}{|l|}{ Stair climb } \\
\hline $\mathrm{BW}(\mathrm{s})$ & $7.48 \pm 1.0$ & $7.18 \pm 0.97$ & $-3.8 \pm 5.4^{*}$ & $7.54 \pm 0.94$ & $7.03 \pm 0.93$ & $-6.56 \pm 7.1^{*}$ & 0.257 \\
\hline $10 \mathrm{~kg}(\mathrm{~s})$ & $7.35 \pm 1.0$ & $7.21 \pm 1.07$ & $-3.3 \pm 5.0 *$ & $7.62 \pm 1.34$ & $7.09 \pm 1.07$ & $-6.29 \pm 8.1 *$ & 0.267 \\
\hline $20 \mathrm{~kg}(\mathrm{~s})$ & $7.91 \pm 1.53$ & $7.58 \pm 1.50$ & $-3.8 \pm 8.4^{*}$ & $8.07 \pm 1.73$ & $7.41 \pm 1.26$ & $-7.26 \pm 8.57^{*}$ & 0.293 \\
\hline Sit to stand (s) & $7.0 \pm 2.1$ & $6.29 \pm 1.3$ & $-8.1 \pm 13.9 *$ & $6.70 \pm 1.20$ & $5.92 \pm 0.97$ & $-11.0 \pm 9.2 *$ & 0.504 \\
\hline MFA type $\mathrm{I}\left(\mu \mathrm{m}^{2}\right)$ & $4519 \pm 1030$ & $4667 \pm 1187$ & $4.7 \pm 22.0$ & $4897 \pm 919$ & $4933 \pm 785$ & $2.8 \pm 19.7$ & 0.823 \\
\hline MFA type II $\left(\mu \mathrm{m}^{2}\right)$ & $3862 \pm 1984$ & $4502 \pm 1397$ & $34.2 \pm 56.7^{*}$ & $3740 \pm 1608$ & $4692 \pm 1441 *$ & $33.8 \pm 27.4^{*}$ & 0.935 \\
\hline
\end{tabular}

Pre and post values are means \pm SD. Changes are percent $\pm \mathrm{SD} ;{ }^{*}$ different from baseline, $p$-value $(p<0.05)$. MFA, muscle fiber area 1 RM, one repetition maximum; $\mathrm{VL}$, vastus lateralis. 


\subsection{Acute Experiment}

The acute bout induced muscular fatigue, measured as a reduction in the quadriceps' force-generating capacity $15 \mathrm{~min}$ after training (native whey: $-11.8 \pm 6.0 \%$ and $-9.5 \pm 3.0 \%$, milk: $-12.4 \pm 4.3 \%$ and $10.0 \pm 5.0 \%$, in the untrained and trained state, respectively, $p<0.001$ for all). Force-generating capacity remained significantly decreased at $24 \mathrm{~h}$ after the exercise bout in the untrained state with milk $(-9.4 \pm 6.7 \%, p<0.001)$ but not with native whey $(-4,2 \pm 5.7 \%, p=0.099)$. In the trained state, no significant differences from baseline compared to $24 \mathrm{~h}$ after exercise were observed with milk $(-4.6 \%, p=0.103)$ or native whey $(-2.8 \%, p=0.414)$

There were no group differences for the recovery of muscle force-generating capacity.

\subsection{Blood Measures}

Fasting plasma concentrations of glucose, insulin, urea, and CK did not change significantly throughout the training period. Acutely, all supplements increased plasma glucose (Figure $4 \mathrm{~A}$ ) and insulin (Figure 4B), with higher levels of glucose in the milk group at $45(p=0.002)$ and $60(p=0.048)$ $\mathrm{min}$, and higher levels of insulin at $30 \mathrm{~min}(p=0.033)$ with native whey after the training intervention. Plasma urea remained relatively stable after exercise and supplement ingestion (Figure 4C). Plasma CK increased $24 \mathrm{~h}$ after exercise with all supplements, with the milk group reaching higher post-exercise levels than native whey before the training intervention (Figure $4 \mathrm{D}, p=0.011$ ).
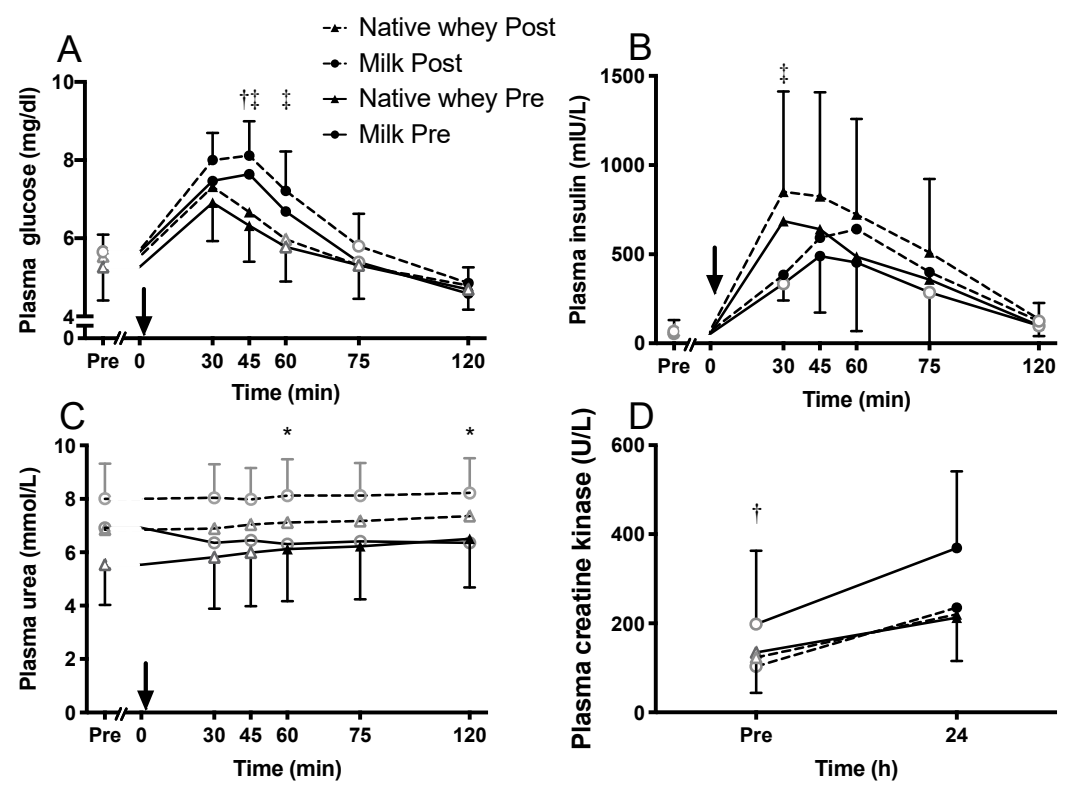

Figure 4. Changes in serum glucose (A), insulin (B), urea (C), and creatine kinase (D) following intake of milk or native whey immediately after a bout of resistance exercise in the elderly. Arrow indicates time point of protein supplement ingestion. Values are mean \pm SD (only shown for highest and lowest values). $n=9$ and 11 in the milk and native whey group, respectively. Data were analyzed with a two-way repeated measures ANOVA (time $\times$ supplement). Multiple comparisons tests were used as post-hoc tests to specify the significant differences between groups (Tukey) and within groups and training states (Dunett). Black data points indicate a difference form resting values; gray hollow data points indicate no significant difference from resting levels. * milk difference between pre and post, † milk and native whey different at pre, $\ddagger$ milk and native whey different at post, $p<0.05$.

\subsection{Amino Acid Concentrations in Blood}

Fasting concentrations of branched chain amino acids (BCAA) and some other essential amino acids (EAA, native whey: Lysine, threonine, and tryptophan; milk: Lysine, methionine, phenylalanine, and tryptophan) increased during the intervention period (data not shown). The acute increase in blood 
concentrations of leucine, BCAA, and EAA were higher after ingestion of native whey compared to milk at 45, 60, and $75 \mathrm{~min}$ after protein ingestion both in the untrained and the trained state $(p<0.001$, Figure 5). Blood concentration levels of leucine tended to increase after milk ingestion before $(45,60$, and 120 min post-exercise, $p$ : 0.068-0.054), and increased after (at $120 \mathrm{~min}$ post-exercise, $p=0.004$ ) the training intervention. The area under the curve for two hours after protein ingestion was higher in the native whey group for leucine, BCAA, and EAA compared to milk in both the untrained and trained state $(p<0.001)$.
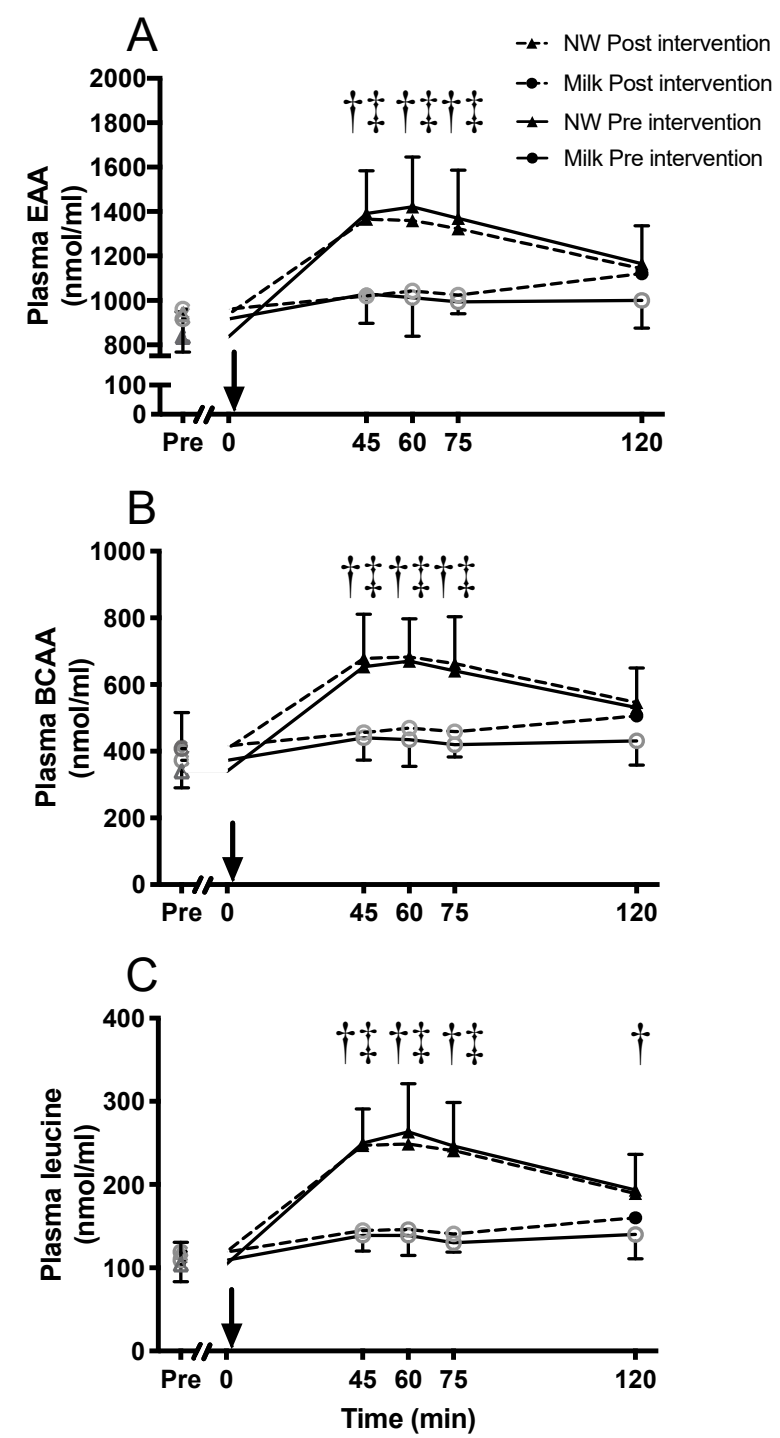

Figure 5. Blood concentrations of total amino acids (A), essential amino acids (B), and leucine (C) following intake of milk or native whey immediately after a bout of resistance exercise in the elderly. Arrow indicates time point of protein supplement ingestion. Values are mean \pm SD (only shown for the highest and lowest values). $n=9$ and 11 in the milk group and native whey group, respectively. Data were analyzed with a two-way repeated measures ANOVA (time $\times$ supplement). Multiple comparisons tests were used as post-hoc tests to specify the significant differences between groups (Tukey) and time points (Dunnet). Black data points indicate a difference form resting values; gray data points indicate no significant difference from resting levels. $\dagger$ milk and native whey different at pre, $\ddagger$ milk and native whey different at post $p<0.05$. 


\subsection{Protein Signaling}

Resting levels of total (milk: $-24.4 \pm 21.2 \%, p=0.009$; native whey: $-23.2 \pm 17.7 \%, p=0.003$ ) and phosphorylated (milk: $-49.4 \pm 27.6 \%, p<0.001$; native whey: $-40.6 \pm 31.3 \%, p=0.002$ ) p70S6K decreased during the training period in both groups. Phosphorylation of p70S6K increased with both supplements in the untrained and trained state after resistance exercise and protein supplementation (Figure 6A). No group differences were observed for p70S6K phosphorylation.
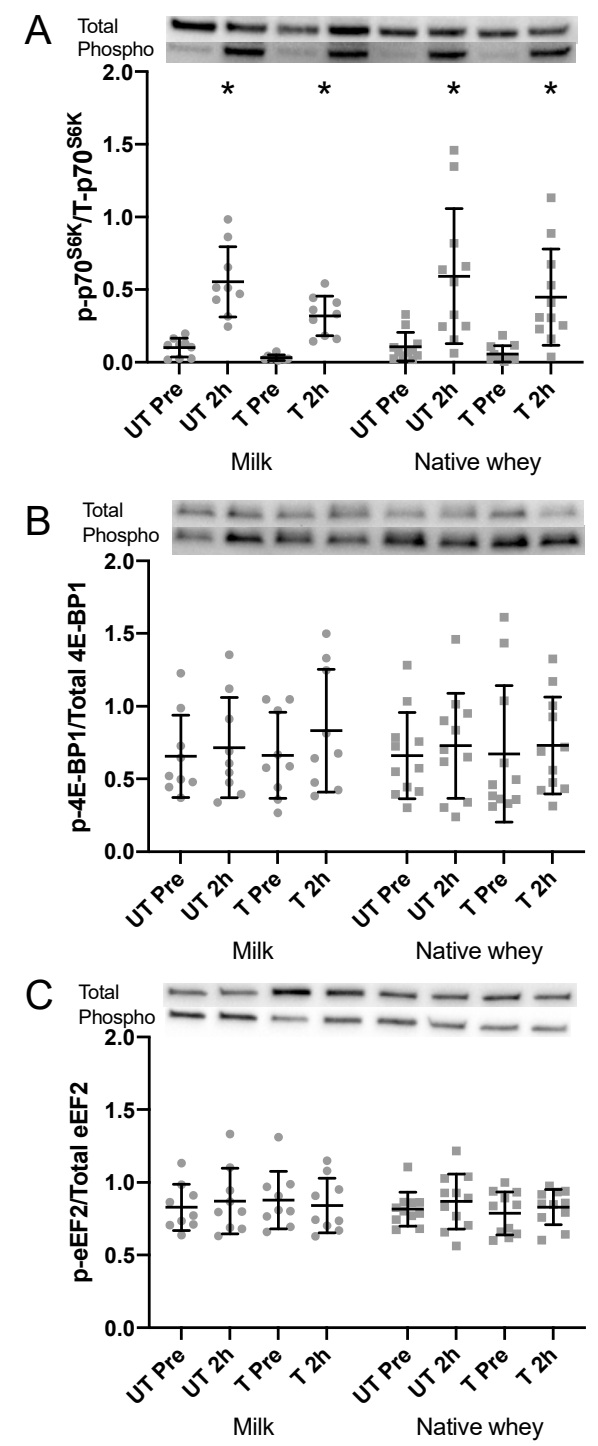

Figure 6. Phospho/total ratio of P70S6K (A), 4E-BP1 (B), and eEF-2 (C) following intake of milk and native whey immediately after a bout of resistance exercise in the elderly. UT: untrained; T: trained. Values are mean \pm SD. $n=9$ and 11 in the milk group and native whey group, respectively. Data were analyzed with a two-way repeated measures ANOVA (time $\times$ supplement). Multiple comparisons tests were used as post-hoc tests to specify the significant differences between groups (Sidak) and time points within groups (Tukey). Relative changes were analyzed with a Student's $t$ test for differences between pre and $2 \mathrm{~h}$ within groups (paired) and between groups (un-paired). ${ }^{*}$ different from pre within group, $p<0.05$.

Resting total and phosphorylated levels of 4E-BP1 and eEF-2 were unchanged during the training intervention ( $p>0.51$ for all, Figure $6 \mathrm{~B}, \mathrm{C})$. No acute changes in phosphorylation were observed for $4 \mathrm{E}-\mathrm{BP} 1$ or eEF-2 in response to resistance exercise and protein supplementation. 


\subsection{Correlations}

Changes in $1 \mathrm{RM}$ leg press showed moderate correlations with changes in stair climb performance $(\mathrm{r}=-0.5$ to $-06, p<0.005)$.

\section{Discussion}

The aim of this study was to test whether supplementation with a leucine-rich native whey protein would result in improved muscular adaptations of growth and strength compared to milk supplementation during 11 weeks of resistance exercise in elderly participants. In order to investigate how signaling related to translation responded to protein intake and resistance exercise changes with training status, an acute study was performed during the first and the last bouts of the training intervention. There were three primary findings: (1) The increase in muscle mass and strength after 11 weeks of strength training was similar between groups supplemented with native whey or milk; (2) we observed no differences between supplements in the effects on phosphorylation of p70S6K, $4 \mathrm{E}-\mathrm{BP} 1$, and eEF-2; and (3) total and resting phosphorylation levels of p70S6K were reduced during the training and supplementation period.

\subsection{Effect of Protein Type on Muscle Mass and Strength}

Resistance training in combination with supplementation of milk protein or native whey was effective in terms of increasing muscle mass and strength in our elderly participants. In contrast to our hypothesis, no differences were observed between the protein supplements. Previous studies have shown that the elderly may need twice the amount of protein as the young to maximally stimulate MPS at rest $\left(0.24 \mathrm{~g} \cdot \mathrm{kg}^{-1}\right.$ vs. $0.40 \mathrm{~g} \cdot \mathrm{kg}^{-1} ;[26]$ and after moderate volume, heavy resistance exercise $(40 \mathrm{~g}$ vs. $20 \mathrm{~g}$; [27]. Furthermore, adding leucine to a suboptimal dose of protein is effective in enhancing the protein synthesis response [28], and may rescue the acute MPS in young and elderly [13-15]. Based on these findings, we hypothesized that, due to our supposedly suboptimal dose of protein ( $20 \mathrm{~g})$ and the difference in leucine content between supplements, native whey would lead to superior stimulation of MPS, leading to a greater accretion of muscle mass over time than milk.

Whey has been found to acutely stimulate MPS to a greater extent than casein in elderly that are rested [8] and have exercised [29], but not all studies report such differences [30]. A recent review suggests the anabolic resistance in elderly substantiate mainly when stimuli are suboptimal [31]. When combining heavy resistance exercise with "optimal" amounts of protein, few studies find evidence for an anabolic resistance in elderly [31]. Thus, in the present study, the combination of high-volume heavy resistance exercise and $20 \mathrm{~g}$ of high-quality protein may have been enough to overcome any potential anabolic resistance and made the higher leucine content in native whey redundant.

Most previous studies investigating the effects of protein supplementation and resistance training in elderly have not reported any significant effects of protein supplementation [19,20,22,32-34]. On the contrary, a meta-analysis by Cermak and colleagues [17] found greater increases in lean mass and 1 RM in leg press, when resistance training was combined with protein supplementation in elderly. Similar findings were reported by a more recent meta-analysis by Morton and colleagues [35] for young but not elderly individuals. Thus, there is some discrepancy regarding what effects we could expect from our protein supplementation in elderly.

We are not aware of previous studies comparing whey and milk/casein supplementation in combination with resistance training in elderly. In contrast to our findings, Hidayat and colleagues [36] observed a greater effect on fat-free mass in studies supplementing with whey protein, compared to casein or milk protein concentrate. Several of the studies on protein supplementation in elderly are challenged by a low number of participants, by not exclusively including elderly participants, and by a suboptimal supplementation in terms of frequency and/or amount of protein [20,22,32-34]. The few studies reporting additional effects of protein in elderly investigated frail elderly populations, where the potential benefits may be greater than in healthy elderly $[18,37,38]$. Without an "optimal" 
intervention it is hard to conclude on the potential effects of protein supplementation in elderly. We observed an average increase in lean mass of $2.1 \mathrm{~kg}$. This is more than the previously reported 0.6 and $1.4 \mathrm{~kg}$ increases in lean mass [18-20,22,32,34,37] after protein supplementation and resistance training in elderly. This may relate to the health state of our participants, which was very good (almost no use of medication) and their high initial activity level, potentially counteracting anabolic resistance and allowing them to complete the demanding training program. By applying an RM-based program, all participants were at or close to failure on the Monday and Friday workouts, ensuring a strong growth stimulus. Unfortunately, without a placebo group, we cannot determine the separate contributions from resistance exercise and protein supplementation on strength and lean mass in our study. Nevertheless, it seems clear that as long as the dietary intake of macronutrients and protein quality is sufficient, the ability for healthy elderly to respond to strength training with large increases in muscle mass is maintained.

In line with changes in muscle mass, we observed no differences in increases in strength or performance in the stair climb or chair rise. The 30\% to $35 \%$ and $20 \%$ increase in 1 RM leg press and chest press, respectively, is similar to results from previous resistance training studies supplementing with protein in elderly [18-20,33,37]. Our moderate correlation between change in 1 RM leg press and change in performance indicates a transfer from strength gains to functional tasks in elderly. Importantly, we did not observe any differences between supplements for any measure of muscle mass or strength. The large variability in individual responses makes it difficult to confidently exclude a type II statistical error in the current study.

\subsection{Amino Acid Concentrations in Blood}

Fasting levels of some individual EAA increased (5-20\%) during the intervention. However, we did not see an increase in fasting levels of EAA as we observed in young individuals [39]. The previously reported association between fasting blood levels of leucine and changes in lean mass [23] was not observed in the current study. As previously reported, the acute changes in blood concentrations of leucine, BCAA, and EAA after protein ingestion were greater with native whey compared to milk [16], both in the untrained and trained state. The blood leucine concentrations after exercise and intake of native whey in the current study are comparable to values previously reported in elderly [16] but lower compared to resistance-trained young individuals ingesting $20 \mathrm{~g}$ of a similar native whey supplement [40]. Somewhat surprisingly, and contrary to substantial previous literature $[8,29,30]$, we only observed tendencies towards an effect of milk ingestion on blood concentrations of amino acids within two hours after ingestion. These data are similar to what we reported in young individuals in a similar study [39], but with some more data points reaching significance. The discrepancy with previous studies is likely due to at least two factors slowing down the absorption of casein in the current study: (1) Most studies used isolated casein, whereas we utilized milk protein combined with fat and lactose to mimic the composition of skimmed milk. The addition of a milk matrix to casein have been shown to slow digestion and absorption of amino acids but not the muscle protein synthesis response [41]; and (2) although rarely stated, it is our impression that most studies use different forms of casein caseinate that are more readily absorbed than micellar casein as it exists in milk. Comparing our results to other studies using micellar casein shows good agreement $[9,42,43]$. It is also important to note that measuring the blood concentrations of amino acids does not allow insight into the flux of amino acids into muscle. This information would require intrinsically labelled amino acids to be ingested.

\subsection{Intracellular Signaling}

Despite large differences in blood concentrations of amino acids, milk and native whey supplementation resulted in comparable phosphorylation of p70S6K two hours after resistance exercise, both in the untrained and trained state. These results go against a previous study by our group, where native whey led to a greater phosphorylation of p70S6K and a concomitant greater 
stimulation of mixed-muscle FSR after exercise, compared to milk [16]. This could be explained by differences in the supplementation regime and timing of biopsies in our previous study, with $20 \mathrm{~g}$ of protein immediately after and $2 \mathrm{~h}$, and biopsies at 1 and $3 \mathrm{~h}$ after resistance exercise. Furthermore, the difference in leucine content per serving between supplements was greater than in the current study (0.76 g vs. $0.59 \mathrm{~g}$; [16]). However, blood concentrations of amino acids, including leucine, over the first $2 \mathrm{~h}$ after ingestion did not differ between studies.

In contrast to Farnfield and colleagues [44], we did not show a reduced p70S6K response to protein and resistance exercise in elderly after 11 weeks of resistance training. Total and phosphorylated p70S6K in the rested state were decreased after the training intervention in both groups. Increasing age has been associated with greater basal mTORC-1 phosphorylation in both mice [45] and humans [46]. Recently, this age-related elevation of mTORC1 activity was linked to muscle fiber damage and loss in mice [47] and its inhibition by a rapalog (RAD001) showed protective effects against sarcopenia in rats [48]. Our findings suggest that resistance exercise may be capable of reducing or normalizing mTORC1 phosphorylation in aging individuals.

\subsection{Recovery of Force-Generating Capacity}

Force-generating capacity was reduced by $5-25 \%$ after the resistance exercise protocol both in the untrained and trained state. Combined with a small increase in CK this indicates a mild to moderate muscular stress [49]. These data agrees well with a previous study, where we found no difference between milk and native whey on recovery of force-generating capacity after a "normal" bout of resistance exercise in elderly [16].

\subsection{Limitations}

We did not achieve the intended number of participants in the current study and the risk of committing a type 2 statistical error is present. However, we still have confidence in our conclusion as we applied several methods to measure muscle mass and strength, and all showed similar results. Differences seem to be small and although the inclusion of more participants might show significant differences, the clinical relevance of these are likely to be small.

The post-exercise supplements were consumed immediately after exercise and had a compliance of $100 \%$. All other supplement intakes were self-reported three times per week. Although, participants were highly motivated, we suspect an overestimation of adherence to the supplementation scheme.

By recruiting participants through the local newspaper and posters on activity centers, we likely missed the most sedate, less healthy segment of this age group. As a consequence, our results may only apply to healthy, active elderly, and not the groups that may benefit the most.

\section{Conclusions}

We observed no differences in muscle mass accretion or gains in strength between milk protein or native whey, when supplemented as $2 \times 20 \mathrm{~g}$ daily servings in combination with strength training. In line with the long-term adaptations, protein supplementation after exercise increased phosphorylation of p70S6K equally with milk proteins or native whey. The resting levels of total and phosphorylated p70S6K were reduced during the training period, but the acute anabolic signaling response to resistance exercise and protein supplementation did not change from the untrained to the trained state.

Supplementary Materials: The following are available online at http://www.mdpi.com/2072-6643/11/9/2094/s1, Table S1: Antibodies.

Author Contributions: Conceptualization, H.H. and T.R.; methodology, H.H., T.R., M.K.J., F.S., M.B., and I.G.; formal analysis, H.H., T.R., M.K.J., F.S. and M.B.; investigation, H.H., M.K.J., F.S. and M.B.; resources, T.R. and H.B.B.; writing—original draft preparation, H.H.; writing—review and editing, T.R., M.K.J., F.S., M.B., I.G. and H.B.B.; visualization, H.H.; supervision, H.H., T.R. and H.B.B.; project administration, H.H. and T.R.; funding acquisition, T.R.

Funding: This research was funded by TINE SA and the Norwegian Research Council. 
Acknowledgments: The authors would like to thank Hege Østgaard at the Norwegian School of Sport Sciences for excellent lab work. The participants are acknowledged for their great contribution.

Conflicts of Interest: The authors declare no conflict of interest. The funders had no role in the design of the study; in the collection, analyses, or interpretation of data; in the writing of the manuscript, or in the decision to publish the results.

\section{References}

1. Baumgartner, R.N.; Koehler, K.M.; Gallagher, D.; Romero, L.; Heymsfield, S.B.; Ross, R.R.; Garry, P.J.; Lindeman, R.D. Epidemiology of sarcopenia among the elderly in New Mexico. Am. J. Epidemiol. 1998, 147, 755-763. [CrossRef] [PubMed]

2. Atkins, J.L.; Whincup, P.H.; Morris, R.W.; Lennon, L.T.; Papacosta, O.; Wannamethee, S.G. Sarcopenic Obesity and Risk of Cardiovascular Disease and Mortality: A Population-Based Cohort Study of Older Men. J. Am. Geriatr. Soc. 2014, 62, 253-260. [CrossRef] [PubMed]

3. Dominguez, L.J.; Barbagallo, M. The cardiometabolic syndrome and sarcopenic obesity in older persons. J. Cardiometab. Syndr. 2007, 2, 183-189. [CrossRef] [PubMed]

4. Naseeb, M.A.; Volpe, S.L. Protein and exercise in the prevention of sarcopenia and aging. Nutr. Res. 2017, 40, 1-20. [CrossRef] [PubMed]

5. Rennie, M.J. Anabolic resistance: The effects of aging, sexual dimorphism, and immobilization on human muscle protein turnover. Appl. Physiol. Nutr. Metab. 2009, 34, 377-381. [CrossRef] [PubMed]

6. Booth, F.W.; Tseng, B.S.; Flück, M.; Carson, J.A. Molecular and cellular adaptation of muscle in response to physical training. Acta Physiol. Scand. 1998, 162, 343-350. [CrossRef] [PubMed]

7. Coffey, V.G.; Hawley, J.A. The molecular bases of training adaptation. Sports Med. 2007, 37, 737-763. [CrossRef]

8. Pennings, B.; Boirie, Y.; Senden, J.M.G.; Gijsen, A.P.; Kuipers, H.; van Loon, L.J.C. Whey protein stimulates postprandial muscle protein accretion more effectively than do casein and casein hydrolysate in older men. Am. J. Clin. Nutr. 2011, 93, 997-1005. [CrossRef]

9. Tang, J.E.; Moore, D.R.; Kujbida, G.W.; Tarnopolsky, M.A.; Phillips, S.M. Ingestion of whey hydrolysate, casein, or soy protein isolate: Effects on mixed muscle protein synthesis at rest and following resistance exercise in young men. J. Appl. Physiol. 2009, 107, 987-992. [CrossRef]

10. West, D.W.; Burd, N.A.; Coffey, V.G.; Baker, S.K.; Burke, L.M.; Hawley, J.A.; Moore, D.R.; Stellingwerff, T.; Phillips, S.M. Rapid aminoacidemia enhances myofibrillar protein synthesis and anabolic intramuscular signaling responses after resistance exercise. Am. J. Clin. Nutr. 2011, 94, 795-803. [CrossRef]

11. Volpi, E.; Kobayashi, H.; Sheffield-Moore, M.; Mittendorfer, B.; Wolfe, R.R. Essential amino acids are primarily responsible for the amino acid stimulation of muscle protein anabolism in healthy elderly adults. Am. J. Clin. Nutr. 2003, 78, 250-258. [CrossRef] [PubMed]

12. Atherton, P.J.; Smith, K.; Etheridge, T.; Rankin, D.; Rennie, M.J. Distinct anabolic signalling responses to amino acids in C2C12 skeletal muscle cells. Amino Acids 2010, 38, 1533-1539. [CrossRef] [PubMed]

13. Atherton, P.J.; Kumar, V.; Selby, A.; Rankin, D.; Hildebrandt, W.; Phillips, B.; Williams, J.; Hiscock, N.; Smith, K. Enriching a protein drink with leucine augments muscle protein synthesis after resistance exercise in young and older men. Clin. Nutr. 2017, 36, 888-895. [CrossRef] [PubMed]

14. Bukhari, S.S.; Phillips, B.E.; Wilkinson, D.J.; Limb, M.C.; Rankin, D.; Mitchell, W.K.; Koboyashi, H.; Greenhaff, P.L.; Smith, K.; Atherton, P.J. Intake of low-dose leucine-rich essential amino acids stimulates muscle anabolism equivalently to bolus whey protein in older women, at rest and after exercise. Am. J. Physiol. Endocrinol. Metab. 2015, 308, E1057-E1065. [CrossRef] [PubMed]

15. Wall, B.T.; Hamer, H.M.; de Lange, A.; Kiskini, A.; Groen, B.B.L.; Senden, J.M.G.; Gijsen, A.P.; Verdijk, L.B.; van Loon, L.J.C. Leucine co-ingestion improves post-prandial muscle protein accretion in elderly men. Clin. Nutr. 2013, 32, 412-419. [CrossRef] [PubMed]

16. Hamarsland, H.; Aas, S.N.; Nordengen, A.L.; Holte, K.; Garthe, I.; Paulsen, G.; Cotter, M.; Borsheim, E.; Benestad, H.B.; Raastad, T. Native Whey Induces Similar Post Exercise Muscle Anabolic Responses as Regular Whey, Despite Greater Leucinemia, in Elderly Individuals. J. Nutr. Health Aging 2019, 23, 42-50. [CrossRef] 
17. Cermak, N.M.N.; Res, P.T.P.; de Groot, L.C.L.; Saris, W.H.W.; van Loon, L.J.L. Protein supplementation augments the adaptive response of skeletal muscle to resistance-type exercise training: A meta-analysis. Am. J. Clin. Nutr. 2012, 96, 1454-1464. [CrossRef] [PubMed]

18. Tieland, M.; Tieland, M.; Dirks, M.L.; van der Zwaluw, N.; van der Zwaluw, N.; Verdijk, L.B.; van de Rest, O.; van de Rest, O.; de Groot, L.C.P.G.M.; de Groot, L.C.P.G.M.; et al. Protein supplementation increases muscle mass gain during prolonged resistance-type exercise training in frail elderly people: A randomized, double-blind, placebo-controlled trial. J. Am. Med. Dir. Assoc. 2012, 13, 713-719. [CrossRef] [PubMed]

19. Chale, A.; Cloutier, G.J.; Hau, C.; Phillips, E.M.; Dallal, G.E.; Fielding, R.A. Efficacy of Whey Protein Supplementation on Resistance Exercise-Induced Changes in Lean Mass, Muscle Strength, and Physical Function in Mobility-Limited Older Adults. J. Gerontol. A Biol. Sci. Med. Sci. 2012, 68, 682-690. [CrossRef]

20. Verdijk, L.B.; Jonkers, R.A.; Gleeson, B.G.; Beelen, M.; Meijer, K.; Savelberg, H.H.; Wodzig, W.K.; Dendale, P.; van Loon, L.J. Protein supplementation before and after exercise does not further augment skeletal muscle hypertrophy after resistance training in elderly men. Am. J. Clin. Nutr. 2009, 89, 608-616. [CrossRef]

21. Hamarsland, H.; Laahne, J.A.L.; Paulsen, G.; Cotter, M.; Borsheim, E.; Raastad, T. Native whey induces higher and faster leucinemia than other whey protein supplements and milk: A randomized controlled trial. BMC Nutr. 2017, 3, 10. [CrossRef]

22. Leenders, M.; Verdijk, L.B.; Van der Hoeven, L.; Van Kranenburg, J.; Nilwik, R.; Wodzig, W.K.W.H.; Senden, J.M.G.; Keizer, H.A.; van Loon, L.J.C. Protein supplementation during resistance-type exercise training in the elderly. Med. Sci. Sport Exerc. 2013, 45, 542-552. [CrossRef] [PubMed]

23. Volek, J.S.; Volk, B.M.; Gómez, A.L.; Kunces, L.J.; Kupchak, B.R.; Freidenreich, D.J.; Aristizabal, J.C.; Saenz, C.; Dunn-Lewis, C.; Ballard, K.D.; et al. Whey protein supplementation during resistance training augments lean body mass. J. Am. Coll. Nutr. 2013, 32, 122-135. [CrossRef] [PubMed]

24. Hartman, J.W.; Tang, J.E.; Wilkinson, S.B.; Tarnopolsky, M.A.; Lawrence, R.L.; Fullerton, A.V.; Phillips, S.M. Consumption of fat-free fluid milk after resistance exercise promotes greater lean mass accretion than does consumption of soy or carbohydrate in young, novice, male weightlifters. Am. J. Clin. Nutr. 2007, 86, 373-381. [CrossRef] [PubMed]

25. Paulsen, G.; Hamarsland, H.; Cumming, K.T.; Johansen, R.E.; Hulmi, J.J.; Borsheim, E.; Wiig, H.; Garthe, I.; Raastad, T. Vitamin C and E supplementation alters protein signalling after a strength training session, but not muscle growth during 10 weeks of training. J. Physiol. 2014, 592, 5391-5408. [CrossRef] [PubMed]

26. Moore, D.R.; Churchward-Venne, T.A.; Witard, O.; Breen, L.; Burd, N.A.; Tipton, K.D.; Phillips, S.M. Protein Ingestion to Stimulate Myofibrillar Protein Synthesis Requires Greater Relative Protein Intakes in Healthy Older Versus Younger Men. J. Gerontol. A Biol. Sci. Med. Sci. 2014, 70, 57-62. [CrossRef] [PubMed]

27. Yang, Y.; Breen, L.; Burd, N.A.; Hector, A.J.; Hector, A.J.; Churchward-Venne, T.A.; Josse, A.R.; Josse, A.R.; Tarnopolsky, M.A.; Phillips, S.M. Resistance exercise enhances myofibrillar protein synthesis with graded intakes of whey protein in older men. Br. J. Nutr. 2012, 108, 1780-1788. [CrossRef] [PubMed]

28. Churchward-Venne, T.A.; Breen, L.; Di Donato, D.M.; Hector, A.J.; Mitchell, C.J.; Moore, D.R.; Stellingwerff, T.; Breuille, D.; Offord, E.A.; Baker, S.K.; et al. Leucine supplementation of a low-protein mixed macronutrient beverage enhances myofibrillar protein synthesis in young men: A double-blind, randomized trial. Am. J. Clin. Nutr. 2014, 99, 276-286. [CrossRef] [PubMed]

29. Burd, N.A.; Yang, Y.; Moore, D.R.; Tang, J.E.; Tarnopolsky, M.A.; Phillips, S.M. Greater stimulation of myofibrillar protein synthesis with ingestion of whey protein isolate $\mathrm{v}$. micellar casein at rest and after resistance exercise in elderly men. Br. J. Nutr. 2012, 108, 958-962. [CrossRef]

30. Dideriksen, K.J.; Reitelseder, S.; Petersen, S.G.; Hjort, M.; Helmark, I.C.; Kjaer, M.; Holm, L. Stimulation of muscle protein synthesis by whey and caseinate ingestion after resistance exercise in elderly individuals. Scand. J. Med. Sci. Sports 2011, 21, E372-E383. [CrossRef]

31. Shad, B.J.; Thompson, J.L.; Breen, L. Does the muscle protein synthetic response to exercise and amino acid-based nutrition diminish with advancing age? A systematic review. Am. J. Physiol. Endocrinol. Metab. 2016, 311, E803-E817. [CrossRef] [PubMed]

32. Arnarson, A.; Geirsdottir, O.G.; Ramel, A.; Briem, K.; Jonsson, P.V.; Thorsdottir, I. Effects of whey proteins and carbohydrates on the efficacy of resistance training in elderly people: Double blind, randomised controlled trial. Eur. J. Clin. Nutr. 2013, 67, 821-826. [CrossRef] [PubMed] 
33. Bemben, M.G.; Witten, M.S.; Carter, J.M.; Eliot, K.A.; Knehans, A.W.; Bemben, D.A. The Effects of Supplementation with Creatine and Protein on Muscle Strength Following a Traditional Resistance Training Program in Middle-Aged and Older Men. J. Nutr. Health Aging 2010, 14, 155-159. [CrossRef] [PubMed]

34. Kukuljan, S.; Kukuljan, S.; Nowson, C.A.; Nowson, C.A.; Sanders, K.; Sanders, K.; Daly, R.M.; Daly, R.M. Effects of resistance exercise and fortified milk on skeletal muscle mass, muscle size, and functional performance in middle-aged and older men: An 18-mo randomized controlled trial. J. Appl. Physiol. 2009, 107, 1864-1873. [CrossRef] [PubMed]

35. Morton, R.W.; Murphy, K.T.; McKellar, S.R.; Schoenfeld, B.J.; Henselmans, M.; Helms, E.; Aragon, A.A.; Devries, M.C.; Banfield, L.; Krieger, J.W.; et al. A systematic review, meta-analysis and meta-regression of the effect of protein supplementation on resistance training-induced gains in muscle mass and strength in healthy adults. Br. J. Sports Med. 2018, 52, 376-384. [CrossRef] [PubMed]

36. Hidayat, K.; Chen, G.C.; Wang, Y.; Zhang, Z.; Dai, X.; Szeto, I.M.Y.; Qin, L.-Q. Effects of milk proteins supplementation in older adults undergoing resistance training: A meta-analysis of randomized control trials. J. Nutr. Health Aging 2018, 22, 237-245. [CrossRef]

37. Dirks, M.L.; Tieland, M.; Verdijk, L.B.; Losen, M.; Nilwik, R.; Mensink, M.; de Groot, L.C.P.G.M.; van Loon, L.J.C. Protein Supplementation Augments Muscle Fiber Hypertrophy but Does Not Modulate Satellite Cell Content During Prolonged Resistance-Type Exercise Training in Frail Elderly. J. Am. Med. Dir. Assoc. 2017, 18, 608-615. [CrossRef]

38. Holm, L.; Olesen, J.L.; Matsumoto, K.; Doi, T.; Mizuno, M.; Alsted, T.J.; Mackey, A.L.; Schwarz, P.; Kjaer, M. Protein-containing nutrient supplementation following strength training enhances the effect on muscle mass, strength, and bone formation in postmenopausal women. J. Appl. Physiol. 2008, 105, 274-281. [CrossRef]

39. Hamarsland, H.; Handegard, V.; Kåshagen, M.; Benestad, H.B.; Raastad, T. No Difference between Spray Dried Milk and Native Whey Supplementation with Strength Training. Med. Sci. Sport Exerc. 2019, 51, 75-83. [CrossRef]

40. Hamarsland, H.; Nordengen, A.L.; Nyvik Aas, S.; Holte, K.; Garthe, I.; Paulsen, G.; Cotter, M.; Borsheim, E.; Benestad, H.B.; Raastad, T. Native whey protein with high levels of leucine results in similar post-exercise muscular anabolic responses as regular whey protein: A randomized controlled trial. J. Int. Soc. Sports Nutr. 2017, 14, 43. [CrossRef]

41. Churchward-Venne, T.A.; Snijders, T.; Linkens, A.M.A.; Hamer, H.M.; Van Kranenburg, J.; van Loon, L.J.C. Ingestion of Casein in a Milk Matrix Modulates Dietary Protein Digestion and Absorption Kinetics but Does Not Modulate Postprandial Muscle Protein Synthesis in Older Men. J. Nutr. 2015, 145, 1438-1445. [CrossRef] [PubMed]

42. Dangin, M.; Boirie, Y.; Garcia-Rodenas, C.; Gachon, P.; Fauquant, J.; Callier, P.; Ballèvre, O.; Beaufrère, B. The digestion rate of protein is an independent regulating factor of postprandial protein retention. Am. J. Physiol. Endocrinol. Metab. 2001, 280, E340-E348. [CrossRef] [PubMed]

43. Boirie, Y.; Dangin, M.; Gachon, P.; Vasson, M.P.; Maubois, J.L.; Beaufrère, B. Slow and fast dietary proteins differently modulate postprandial protein accretion. Proc. Natl. Acad. Sci. USA 1997, 94, 14930-14935. [CrossRef] [PubMed]

44. Farnfield, M.M.; Breen, L.; Carey, K.A.; Garnham, A.; Cameron-Smith, D. Activation of mTOR signalling in young and old human skeletal muscle in response to combined resistance exercise and whey protein ingestion. Appl. Physiol. Nutr. Metab. 2012, 37, 21-30. [CrossRef] [PubMed]

45. Baar, E.L.; Carbajal, K.A.; Ong, I.M.; Lamming, D.W. Sex- and tissue-specific changes in mTOR signaling with age in C57BL/6J mice. Aging Cell 2016, 15, 155-166. [CrossRef]

46. Markofski, M.M.; Dickinson, J.M.; Drummond, M.J.; Fry, C.S.; Fujita, S.; Gundermann, D.M.; Glynn, E.L.; Jennings, K.; Paddon-Jones, D.; Reidy, P.T.; et al. Effect of age on basal muscle protein synthesis and mTORC1 signaling in a large cohort of young and older men and women. Exp. Gerontol. 2015, 65, 1-7. [CrossRef] [PubMed]

47. Tang, H.; Inoki, K.; Brooks, S.V.; Okazawa, H.; Lee, M.; Wang, J.; Kim, M.; Kennedy, C.L.; Macpherson, P.C.D.; $\mathrm{Ji}, \mathrm{X}$.; et al. mTORC1 underlies age-related muscle fiber damage and loss by inducing oxidative stress and catabolism. Aging Cell 2019, 18, e12943. [CrossRef] 
48. Joseph, G.A.; Wang, S.; Zhou, W.; Kimble, G.; Tse, H.; Eash, J.; Shavlakadze, T.; Glass, D.J. Inhibition of mTORC1 signaling in aged rats counteracts the decline in muscle mass and reverses multiple parameters of muscle signaling associated with sarcopenia. bioRxiv 2019, 73, 591891.

49. Paulsen, G.; Mikkelsen, U.R.; Raastad, T.; Peake, J.M. Leucocytes, cytokines and satellite cells: What role do they play in muscle damage and regeneration following eccentric exercise? Exerc. Immunol. Rev. 2012, 18, 42-97.

(C) 2019 by the authors. Licensee MDPI, Basel, Switzerland. This article is an open access article distributed under the terms and conditions of the Creative Commons Attribution (CC BY) license (http://creativecommons.org/licenses/by/4.0/). 